\title{
Inside the Concept: Rethinking Dōgen's Language
}

\section{Rein Raud}

One of the most characteristic features of the philosophy of Doggen is his idiosyncratic use of language, in particular, the replacement of expected semantic connections between two adjacent Chinese characters with improbable, but grammatically possible ones, from which new philosophical concepts are then derived. The article places this writing technique in the context of the linguistic changes that were taking place both in China and Japan at the time of Doggen's writing as well as the general attitude of Chan/Zen thinkers toward language, arguing that the Chan/Zen critique was not pointed to language as such, but its reified and alienated forms. Doggen's concept-making could accordingly be seen as an effort to keep language 'alive.' The article offers two possible ways of interpreting his concepts: they can either be seen as relativisations of the mainstream reading norms, or as the creation of total semantic links in which all the existing ways of linking two characters are simultaneously possible.

One of the most satisfactory definitions of philosophy, which enables us to group under this label a large variety of intellectual/cultural practices, traditions, texts and authors from all times and parts of the world, is formulated by Gilles Deleuze and Felix Guattari: 'philosophy is the art of forming, inventing and fabricating concepts' (1994, p. 2), and ' $\mathrm{t}]$ he object of philosophy is to create concepts that are always new' (1994, p. 5). A concept, in their view, is not just a technical term to designate some precisely defined notion, the smallest element of a systematic network that can be used to adequately describe their particular vision of reality and its architecture, but:

the contour, the configuration, the constellation of an event to come. [...] The concept is obviously knowledge-but knowledge of itself, and what it knows is the pure event, which must not be confused with the state of affairs in which it is embodied. The task of philosophy when it creates concepts, entities, is always to

Correspondence to: Rein Raud, Tallinn University, Uus-Sadama 5, Tallinn 10120, Estonia. Email: rein.raud@tlu.ee 
extract an event from things and beings, to set up the new event from things and beings, always to give them a new event: space, time, matter, thought, the possible as events. (1994, pp. 32-33)

This point of view is especially relevant for philosophers, whose relationship with language is highly problematical. All traditions have their share of such thinkers, and Dōgen Zenji (1200-1253) is definitively one of them, being probably the most linguistically sophisticated thinker ever to have emerged from Japan and also surely in the top group of the whole world as well. All Dōgen researchers point out his deliberate twistings of quotes from the scriptures and his readings, which are definitively misinterpretations from the point of view of commonsensical logic. Nevertheless his philosophy is based on such readings, and even his views on everyday life and monastic practice are remotely derived from them.

The aim of the present article is to try to approach Dōgen's relationship with language in the context of his practical technologies of concept-formation, particularly his usage of Chinese words and technical terms used and embedded, although not quite seamlessly, in his Japanese text. In a seminal article, Hee-Jin Kim (1985) has argued that Dōgen's language presents an effort to transcend the apparent illogicality of the kōan and to arrive at the philosophically and rationally conceivable reality beyond it, and by using language as he does to reconfigure both the reality perceived by the mind and the mind that perceives the reality, which is tantamount to enlightenment: 'To Dōgen the manner of expression is as important as the structure of thought; in fact, the experimentation with language is equivalent to the construction of reality' (Kim, 1985, p. 60); moreover, any kind or perception that might form the basis of an utterance is already not neutral: 'seeing itself is fundamentally creating and making... [I]t concerns itself not only with seeing things as they are but creating things as they are meant to be' (Kim, 1985, p. 59). There is much truth in this. However, the status of language is in Kim's view construed fully from the intrinsic development of Chan/Zen practice, in the form preferred by Dōgen. But this is just one side of the coin. Dōgen's texts were written under circumstances where substantial changes were taking place in the whole linguistic environments of both Chinese and Japanese: since the second half of the Tang dynasty, the classical Chinese (wenyan) was being infiltrated by the spoken language in many spheres of textual culture in China, resulting in the gradual emergence of baihua, or written Middle Chinese, and in Japan the official languages-the Sino-Japanese, or kambun of bureaucratic documents and the Japanese of court literature-were yielding their positions to a mixed style of written expression. My aim is to look at Dōgen's linguistic practice in the context of the heightened linguistic awareness that the instability of such a situation warranted and to supplement the previous evaluations of Dōgen's language by Kim and other scholars with conclusions that suggest themselves as we observe the broader background. To start, however, a brief review of Chan/Zen attitudes toward language is in order. 


\section{Chan/Zen and Language}

The received view of Chan/Zen attitudes toward language is built on the first two lines of a programmatic poem attributed to Bodhidharma, the semi-legendary founder of the school:

\section{教外別伝 Transmitted outside schools}

不立文字 Does not rely on letters

直指人心 Directly points to the human mind

見性成佛 Perceives its nature and realises Buddhahood

The poem asserts fairly directly that the Zen 'message' cannot be correctly transmitted through rigid institutional and textual structures. Another classical passage on the non-verbal core of Zen is, of course, the story of the alleged establishment of the tradition, the episode where the Buddha, walking with his disciples, silently raises a flower to them instead of preaching, and Mahākāśyapa alone responds adequately with a smile. However, neither of these texts should be read as a rejection of language in favour of speechless, but still unambiguous communication. Indeed, Chan authors themselves have, from fairly early on, pointed out that significant silence as a means of communication is not problematic. For instance, there is more than just Linji-style authority-bashing in the comment on the Buddha-episode by Wumen Huikai, the compiler of the Wumenguan:

\section{無門 c 黄面篗量c 傍若無人。壓良爲賤c 縣羊頭賣狗肉c 將謂c 多少奇特c 只如當時大睬都笑 c 正法眼藏c 作麼生傳c 設使迦葉不笑 c 正法眼藏又作麼

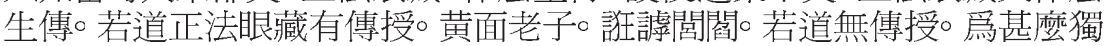 許迦葉。}

\section{Wumen says:}

the golden-faced Gautama thought nothing of others. He treated the good ones as dirt and sold dog meat as if it were the head of a lamb. He must have thought it some wonder. But what if the whole bunch of monks would have roared with laughter? What about the 'the storehouse of the true dharma-eye'? How would he have transmitted it then? Or, say, if Mahākāśyapa had not smiled? What would he then have done with this 'storehouse of the true dharma-eye'? If he says there is some 'storehouse of the true dharma-eye' to be transmitted, he is just a goldenfaced old teacher cheating village boys. If he says there is nothing that could be transmitted, what then did he entrust only to Mahākāśyapa? (Mumonkan, case 6; Nishimura, 1994, pp. 43-44)

If we suppose that this incident has historically taken place (as Wumen may have thought), but make the distinction between the historical Buddha, who actually took part in it, and the literary character called Buddha, who figures in Buddhist texts which include descriptions of this episode, then we can read Wumen's remarks as a warning to distinguish between two kinds of linguistic strategies. Assuming that Buddha was here trying to communicate a 'message' that had actually existed in an unambiguous form prior to the incident is tantamount to reifying him and his teachings, placing him on the fixed trajectory of the literary character; but this 
does not mean that in a concrete setting such communication may not, ad hoc, have taken place. It is well known that what Chan purports to convey in such acts of communication is not a verbalisable message, but a state of mind called enlightenment. Consequently, if language is, at some point, used to these ends, there should be nothing objectionable about it. If, however, language is used to congeal and thereby to falsify what is being passed on in such spontaneous acts, it is dangerous and should be criticised. Language has the power to do that, but alternative strategies of communication employed by Chan, such as slaps and shouts, may become reified just as well. A multitude of passages in the recorded sayings of Chan masters indicate mistrust of whether someone's allegedly 'spontaneous' answer of this kind is, in fact, genuine or an imitation of others.

In some Chan texts, the distinction is made between 'living' and 'dead' words, where 'living' words are conducive to enlightenment, but 'dead' words are pointless chatter and bookish speculations of no real value. 'Living' words also yield themselves to contextualisation and practical reinterpretation, while 'dead' words are rigid in their significance. The idea seems to have been derived from a passage in the Dharmakșema translation of the Mahāparinirvāna sūtra (Takakusu \& Watanabe, 1961, 415c03), although there the expression means 'words of death' rather than dead words. Thus, the construction of 'dead words' as opposed to 'living words' out of this passage is voluntaristic (and entails reading it as 'living words,' so to say), but the repeated used of the character 句 jù (a 'phrase' or 'line of verse' more adequately than a 'word') in later contexts suggests that sutra authority is being used here for other purposes. For instance, we find the expression 11 times in the Biyanlu (cases 39, 41, $42,48,64,68,70,89,93,95,98$ ), always in similar framing to praise someone: 他參 活句c 不參死句。 'He was engaged in living speech, not in dead speech.' Several occurrences in other Chan texts show that it must have become a sort of a stock phrase to appreciate someone's apt reply to a tricky situation. It should be noted that some of such 'living words' may not be linguistic at all, as this expression has also been used to praise Zhaozhou for putting his sandals on his head in case 64. Thus, 'living words' are an utterance, verbal or non-verbal, that functions in a concrete setting, going beyond its referential meaning, while 'dead words' are such that can be repeated without loss to their significance in any context and therefore fail to catch the unrepeatable moment in an exchange.

'Dead' and 'living' words correspond almost fully to the two modes of communication Youru Wang has called 'direct' and 'indirect,' where 'direct communication' is 'speaker-oriented and assumes a linear, teleological relation between the speaker and the receiver; it presupposes the direct or corresponding relation between language and thought, though and object; it regards the message or what is communicated as objective, context-free and separable from existenio-practical concerns; it confers meaning determined, unequivocal, and transparent,' while 'indirect' communication is 'listener- or reader-oriented, and non-teleological; it assumes an interactive relation between the speaker and the listener; it abandons the correspondence theory of language' (2000, pp. 7-8). Wang's observation that in various schools of 20th century European philosophy the focus of attention has shifted from 'direct' to 
'indirect' communication (2000, p. 8) is very much to the point, and it is precisely this tendency that makes also us ready to look at radical Chan or Dōgen as more than just bizarre linguistic experimentation. Dale S. Wright has equalled this shift with the move from a 'modern,' 'instrumental' theory of language to a 'postmodern,' 'existential' position:

Modern thought has located language in the derivative and subsequent roles of description and expression; postmodern thought locates it more primordially, in experience itself. Even before we get around to describing experience, language is already there as the form or forms that the experience has taken. (2000, p. 71)

Where do we find language in everyday experience? Not primarily in abstraction as a system available when we must communicate. Instead, we find it in association with things and situations. We find it already in the world. Language constitutes a dimension of any experience. [...] We experience 'it', therefore, in each of the language forms and in the relation between them, but never on 'its' own. (2000, p. 69)

Although Wright's view at first glance seems to agree very well with the Chan position and his critique of the 'instrumental' model (which is fairly similar to Wang's 'direct communication') is certainly justified, the claim that language is always previously inscribed in our experience of the world needs further investigation. For reading Dōgen, this is a crucial point and merits going into some detail.

Wright's thesis assumes that there is an unproblematic correlation between each fact of (my) experience and the linguistic means at (my) disposal to describe (my) reality. However, these two can well be separate. For instance, I can know from the study of Japanese literature a large number of plants by name, although these do not grow in my country, and I am also familiar with the literary associations that are attached to them. So, in a certain manner, I can operate with these words and meaningfully interpret utterances that contain them. However, seeing one of these plants in reality does not necessarily trigger the same associations in my mind simply because I remain happily unaware that this is the plant in question before somebody points it out to me. This is true of anything that I know, so to speak, 'linguistically,' but not 'really.' At a social gathering I may talk to somebody I know by name without realising that this is the person in question. In fact, the very absence of linguistic conditioning enables me to look at what I see more 'directly,' using the word here as in the 'pure experience' of William James (1904) and Nishida Kitarō (1911), rather than Wang's 'direct communication.' The received view of Chan/Zen texts suggests that precisely such direct, unmediated attitude to reality also underlies the enlightenment experience. Therefore, if we say that language is present in our experience of the world, it is there because we have put it there-we have premodelled, or, if you wish, contaminated our experience with language before we start to process it consciously with whatever analytical means at our disposal. Thus, insofar as it is modified by language, our experience is not pure and innocent, and that should be duly noted. 
Another, and, thinking of Dōgen's case, an even more relevant difficulty in Wright's view is the question of whether our experience has been fused with a particular language (the Sapir-Whorf hypothesis) or are we thinking of one general language, a variation of Steven Pinker's 'mentalese,' a universal language of thought (Pinker, 1995, p. 81), which presupposes a universal grammar based on theories (Husserl, 1900; Chomsky, 1965) of a logical structure of the world allegedly recognised and shared by all natural languages on a deep level. Wright's criticism of the early Chan readings of John Blofeld seem to indicate that this is not the case:

On Blofeld's view, language and culture are "particularities" which do not touch upon the deep, and therefore, "universal," "recesses of the spirit." The untrammeled island of romantic imagination is the place where particulars, like religious ideas and practices, won't stand in the way of the Universal Truth hidden securely behind them. If Huang Po's Mahayana tradition is right, however, then the "universal"- "emptiness"-only makes its appearance, and only exists, within the particularities of "form." (2000, p. 77)

The internal order of the Chinese language resists any attempt to construct a universal grammar rather vigorously, and linguistically conscious thinkers such as Dōgen, who worked on the borders of two structurally quite different linguistic systems, obviously had to problematise the relation between natural language(s) and reality, and it seems that neither of the possible solutions to the question posed above is able to explain the dichotomy of 'living' and 'dead' words satisfactorily.

In view of the above, we could perhaps approach the two Chan attitudes to language/communication in the context of the two modes of linguistic reality posited by Ferdinand de Saussure, that is, 'language' (langage) and 'speech' (parole). Saussure's 'language' is the abstract level of language, constituted by sets of rules and linguistic building blocks, which are in a systematic relation to each other, while the concrete praxis of 'speech' follows, but also violates these rules according to the particular context of a situation. To be more precise: in 'speech,' communicating parties use the elements of 'language,' some more consciously than others, by choosing to bend to their rules when necessary and to twist or ignore them when this suits them better. This, of course, is not to say that all parole would necessarily be 'living' and all langage 'dead' - the distinction between 'living' and 'dead' words can only be made on the parole level, according to the degree of independence and context-boundedness of the utterance. The 'living' character of a phrase lies in its 'speechliness,' while universally repeatable sentences formulated strictly by unmodified rules are more likely 'dead.' Let us note is passing that Saussure's dichotomy has also been successfully transposed to other signifying systems and cultural practices by later authors such as Roland Barthes (1990), and the idiosyncratic, situationally oriented behaviour of radical Chan masters (or literary figures fashioned on them) displays a similar attitude throughout: the rules and norms of everyday life can be followed and made use of, but not blindly, and whenever it is necessary to abandon them in order not to distort their practice, they do so without hesitation.

By no means does the analogy with the two-tier model of linguistic reality entail a return to the instrumental theory justly criticised by Wright, because, for such a 
theory, not only must the words we use be in correlation with reality, our thoughts should also be completely expressible in words. Enlightenment, as well as any other completely unproblematic relationship with reality is, by all definitions, reported to be beyond such correlations. This makes the instrumental theory an even cruder approximation of the two-tiered relationship, because in practice 'speech' can open up to spontaneous play. The difference could be illustrated by a story related by Alan Watts, about an anonymous Zen master drinking tea with two students and tossing his fan unexpectedly to one of them, asking what it was. The student started fanning himself. The other student, when asked the same question, did better: first, he scratched his neck with it, then opened the fan and offered the master a piece of cake on it (1957, p. 150). While the behaviour of the first student was congruent with the instrumental theory, the other acted in liberated parole. This kind of communication is what has been called the 'field of play' by Jacques Derrida:

If totalization no longer has any meaning, it is not because the infiniteness of a field cannot be covered by a finite glance or a finite discourse, but because the nature of the field - that is, language and a finite language-excludes totalization. The field is in effect that of play, that is to say, a field of infinite substitutions only because it is finite, that is to say, because instead of being an inexhaustible field, as in the classical hypothesis, instead of being too large, there is something missing from it: a center which arrests and grounds the play of substitutions. (2001, p. 365)

On the whole it thus seems that what classical Chan/Zen mistrusts is langage and what is automatically derived from it, while endorsing any liberated occurrences of parole: Chan/Zen is not against norms or language (this would create a duality), but dismisses rigid, unbending norms and reified, lifeless language.

In fact, this view does not contradict the meaning of Bodhidharma's verse, which speaks critically about 'letters' 字 ji, i.e. scriptures and other writings, and not 'speech' or 'words' 言 yán, whereas the requirement for the right 'word' in a particular situation is a well-known recurrent motif in Chan lore. The 'letter' of this opposition is contextually fixed, the 'word' is dynamic. Indeed, 不立文字 'does not rely on letters' does not even mean that scriptures should be read, but that they should not be relied upon as static, unchanging and reifiable textual entities. In this respect, the role of scriptures is not unlike the position of the literary canon of a cultural tradition as once defined by Dominick LaCapra: literary works stay canonical if they have 'complex ideological, critical, and at times possibly transformative implications' not only for their own, but also for subsequent cultural contexts (1989, p. 140).

In a sense, then, the key feature that should promote a text to the literary canon or grant it the status of a scripture is its productivity, its ability to generate new, legitimate and meaningful interpretations when exposed to different socio-cultural and personal contexts - in addressing the context of the place and time of their own production they must simultaneously address as many other contexts as possible so that these would be willing and able to adopt them for their own needs. (They must also have a bit of historical luck, no doubt.) In the case of philosophical texts, this means that they will have to remain conceptually productive, the concepts they 
enact must stay dynamic and multivalent-in other words, precisely the kind of concepts Deleuze and Guattari are talking about. This, in turn, presupposes that the texts are being transmitted in an atmosphere that resists rigid institutionalisation and authoritative regulation of hermeneutic practice, 'editorial gatekeeping,' as Wright calls it (2000, p. 10). Of course it is clear that such a tendency was nevertheless also present, and sometimes even prevailed, in later Chan and Zen institutions (just as in any other cultural practice with sufficient status, contemporary academia being no exception), but at its most productive moments, the tradition was well up to the task of keeping textual interpretation a living, dynamic practice. Dōgen's work is perhaps the place where can be seen most distinctly.

\section{Dōgen's Linguistic Medium}

Dōgen's Shōbōgenzō is the first major philosophical work to have been written in Japanese and, whatever his other considerations for the choice of his linguistic medium may have been, even a cursory analysis makes it unmistakably clear that the ideas expressed therein could not have been adequately formulated in Chinese, which, for the genre, would have been more customary. In fact, the work appeared at a time when the system of the stylistic and linguistic registers of Japanese culture was undergoing considerable change. During the Heian period, the stylistic axis of texts had stretched between two poles: kambun, or Sino-Japanese, a variation of classical Chinese used mostly for factual and official texts, and kana, or classical Japanese with a minimal number of sinograms, for poetic and fictional texts with emotionally loaded content. Since the beginning of the 10th century both poles enjoyed high public status, but texts were considered to be high status only as long as they were close enough to either of these two poles with their stylistic constraints. As a result of the cultural changes of the 12th century, this hierarchy of styles started to crumble and a new, mixed style was on the rise. On the one hand, Japanese interlinear glosses were introduced to some kambun texts and, on the other hand, sinograms gradually came to be used in larger quantities in kana texts, pronounced in the Chinese manner (ondoku). These changes occurred predominantly in the generically less regulated parts of the discursive space and initially did not affect the established system of genre hierarchy, thus, that poetry continued to be composed without virtually any Chinese loanwords went without saying; also treatises on courtly poetry were normally supposed to be written in kana or in kambun, but not in the mixed style. For instance, Fujiwara no Teika, the leading poet and philologist of the times, expressed his views in two content-wise fairly similar texts, Eiga Taigai in kambun and Kindai shüka in Japanese.

However, in essayistic pieces with Buddhist content, such as the Hojoki by Ren'in (Kamo no Chòmei) and pedagogical literature (kana hogo) basically meant for less educated laymen, the new style gradually established itself as the expected medium. Although Dōgen's writings, extremely complicated as they are, could hardly have been meant for a very wide audience, he chose to align his writing with such works 
rather than with Buddhist theoretical treatises in Chinese, the institutional status of which was unquestionably much higher.

At the same time, gradual changes also took place in the Chinese linguistic politics. Since the latter half of the Tang dynasty, and largely due to innovations that came from the Buddhist community, there appeared a written language called baihua, or Middle Chinese, which started to displace classical written Chinese, or wenyan, in several spheres of usage. While wenyan maintained its position as the elegant and refined language of poetry, baihua was the medium initially used for a large amount of 'low-cultural' functions, including popular stories and verse, and later also drama and novels, until it finally replaced wenyan as the main vehicle of written expression (Chen, 1999, pp. 68-70). The introduction of woodblock printing that made the business of text production a profitable endeavour further strengthened the position of the vernacular. Needless to say, baihua, so much closer to the spoken language, was also preferred by Chan monks for writing down the sayings of teachers, as well as the authors of bianwen works (retellings of less accessible 'high-cultural' works, such as histories, but also Buddhist scriptural texts). Thus baihua was the main cultural language of the Buddhist communities, although the tensions between it and wenyan must have been perceptible, especially for someone who had to learn the language(s). It should also be noted that the increase of its use and its growing legitimacy in an ever broader array of functions coincided with the period of the rise of NeoConfucianism, which brought with itself an intense period of philological work, including strong challenges to previously canonical interpretations of old works. In particular Zhu Xi, who died in the year Dōgen was born, had introduced critical reading of old texts into the standard practice of philosophy. It is difficult to say to what extent these processes affected the practice and attitude toward textual heritage in Chan monasteries, but we may assume that many of their inhabitants had been exposed to some Confucian training during their lives and therefore it would be natural to assume that the current trends were not altogether unknown also in Chan circles.

All in all, we can say that the languages which Dōgen used were all very much in transition and that may have influenced his views on language as such, as well as prompted to him new ways of how to use language to express his own thoughts and insights. In my opinion, the main reason for Dōgen's choice of mixed style Japanese for his linguistic medium was a need to look at Chinese-bound concepts from the outside. His notorious way of deliberately reading Chinese scriptures in grammatically possible, but semantically improbable ways presupposed a different linguistic medium wherein these readings could be articulated. Nevertheless, the concepts used in Dōgen's discourse - and this is a major difficulty — are frequently left undefined and their idiosyncratic meanings also have to be derived from the context or grasped intuitively. So, we might say that some of Dōgen's thinking is, so to say, thinking-in-Chinese that stays Chinese in this text, but some is opened up to thinking-in-Japanese (and from these openings we can realise how deviant it is from what could normally be expected) and some is regular thinkingin-Japanese. 


\section{R. Raud}

\section{Concepts and Reality}

Typically, a Chinese loanword in Japanese consists of two sinograms, which form one single concept. Such compounds may act, with minimal grammatical modifications, as any semantically adequate part of speech and also alternate freely between them. For example, we would normally expect the expression genjōkōan to be a noun, but in the text we also find it in the role of the verb, translated by Thomas Kasulis as 'to presence' or 'presencing' (1989, p. 83). Also, in modern Chinese, most dictionary entries are such compounds, but in classical Chinese both halves of these concepts were normally seen to be semantically independent. In the 13th century, the process of fixation of compounds into words was already well under way. The tension between spoken and classical Chinese enabled linguistically conscious authors, Dōgen among them, to establish and undo the binary connections between single semantic units more or less at will, or also to try to change them.

There are five possible relations between the two elements of a compound:

- juxtaposition, as in 山水 'mountain (and) water' i.e. landscape, where the relation between the two sinograms is equal;

- attribution, as in 佛性 'Buddha-nature,' where the former is an attribute of the latter;

- predication, as in 要小 '(the case when a) need (is) small,' where the second is a predicate of the first;

- direction, as in 得悟 'achieving enlightenment,' where the first sinogram points to a concept that is directed toward the second, which becomes its grammatical or logical (direct or indirect) object, but it should be noted that the relation of direction is wider than the verb-object relation in most Western languages;

- modification, as in 以前 '(by) before,' this is the case where one of the two sinograms, usually the first, is unable to stand on its own in its present meaning.

Dōgen's idiosyncratic readings of Chinese texts are very frequently based on presupposing a different relation between the parts of a compound that would logically suggest itself. In so doing, Dōgen resurrects the 'reading technology' of ancient Chinese texts that did not make use of so many fixed and static compounds and the relation between any two sinograms had to be determined on the spot at any point in the text-the relations were, so to speak, alive-a technique Faure (1991, p. 114) and Heine (2004, p. 5) call 'atomisation.' The same technique had also been brought back to use in Song China; for instance, Wang Anshi (1021-86) re-interpreted the Daodejing in a sometimes crucially different manner with the same technique (see Wang, 1998, pp. 27-28).

However, Dōgen also frequently makes use of exactly the opposite technique of constructing an as-if fixed compound out of sinograms that stand next to each other in a text, but which are not stably grouped together or perceived to form a distinct concept. Such a compound is then used as if it had always been there and we should certainly have noticed it before, and it is integrated into the web of all remaining concepts with apparent ease. 
I think that among the seven characteristics of Dōgen's language outlined by Kim (1985), all those not relying on phonetic associations or Japanese syntactic constructions can be reduced to these two techniques. For example, transposition of lexical components and semantic reconstruction through (Chinese) syntactic change are variations of relation displacement, the upgrading of commonplace notions is based on concept positing, while the explication of semantic attributes and reinterpretation based on the principle of absolute emptiness may contain elements of both. And since these two techniques are basically the two sides of the same coin, we may say that Dōgen's language is mostly based on one thoroughgoing fundamental principle, that of the reconfiguration of linguistic reality by dissociation from its surface logic. Relations that present themselves to us as natural-and perhaps even as existing in the world-are displaced, and other possibilities tried out, until whatever seems to express best what has to be expressed appears.

I will now present two alternative lines of argument as to how this linguistic behaviour could be explained as a method of philosophical concept-formation, both having important and mutually incompatible consequences. The first narrative assumes that the concept expressed by the compound is a combination of the two sinograms involved. We may presuppose that although the building blocks of the Chinese language, as is well known, cannot be divided into parts of speech in the same way as in inflective or agglutinative languages such as those of the Indo-European family or Japanese, some sinograms are still more predisposed toward forming certain relations to others or toward standing in a certain position. Thus, what we would call transitive verbs in an Indo-European language would be likely to appear in a relationship of direction to the following sinogram, and what we call adjectives would rather appear as attributes to the following or predicates of the preceding sinogram. This quality, termed 'functional preference' by Christoph Harbsmeier (1998, p. 129), but which I would here prefer to call valence, is of great help in reading a text, because it helps us to select the more likely relations between sinograms without having to test them all. But it also endows the reality that the text describes with a certain logical structure: the valences of the sinograms, we may assume, are not a convention of our language, but a reflexion of some qualities that are fundamentally there in reality. If every single sinogram refers to one single referent (we might usually call it a concept, but for the sake of clarity let us here call it its principle-something that unites all the possible referents of the sinogram between themselves) and each principle has certain valences, then it follows that the world, taken at face value, is logically organised. Moreover, since the appearance of the earliest Chinese texts the language has also been structured by the principles of antithetic parallelism, raised to the rank of poetic requirements in regulated verse: not only antithetic pairs but even stable couplings of juxtaposed sinograms (such as 'flowers and birds,' for example) were considered to form pairs of related concepts, which were expected in the same position and function in sentences structured in a parallel way (see the classic exposition of this phenomenon in Liu, 1966, pp. 146-150). Thus the predilection of a word toward juxtaposition with certain other sinograms defines its place in the system of things, a culturally organised 
life-world about which one can speak in a lucid and definite way even if the linguistic medium used for the purpose is characterised by a lot of structural ambiguity.

From the Buddhist point of view, of course, such a logical structure is mere appearance. And this is why Dōgen deconstructs it, by leaving only the building blocks in place, but taking away the relations that combine them into a tight network. When we look at language-or parole, to be exact-with the same uncontaminated gaze with which we should approach the world, we have a more direct access to the principles that the sinograms refer to, and can conjoin them into concepts at will. A concept is thus born of the co-occurrence of two principles in our mind, and we can create them as they are meant to be, just as Kim said (1985, p. 59).

But it is also possible to describe Dōgen's linguistic behaviour in a fundamentally different and even more radical way. It seems quite justified to reject as illusory not only the logical structure that suggests itself as a seemingly natural way to organise our designations of things in the world, but the whole system as such. There is no reason why we should take sinograms and the principles they refer to as a given: isn't it obvious that these principles are themselves contingent derivations of reality and not its inherent characteristics? In such light, we might see Dōgen's attitude toward the relations between sinograms as an effort, by proxy, to displace the sinograms themselves not simply by depriving them of their habitual valence but by totally disconnecting them from the system. The valence of a sinogram is its external conceptual form that is related to its semantic content, or its principle. By adopting the view that any sinogram has universal valence we do not displace one possible relation in favour of another, but deny the specificity of the relations in general: any two sinograms standing beside each other are engaged with each other in all possible relations. This total relation that comprises all possible others is the real relation between two sinograms, the receptacle that allows them to produce a concept, and precisely by containing them all, the relation is in itself empty. Sometimes this relation can also be indicated by some separate words which are enlisted for the effort out of their context. Similarly to the force of vacuum, this empty relation attracts linguistic designations, forces them upon each other and produces concepts out of their clashes. These are no longer random combinations, nor are they the manifestation of the sinograms' natural valences, but the realisation of the metarelation, which has organised the lexical material around itself, not vice versa.

Let us look at an example:

あるいは即心是佛を參究し、心即佛是を參究し、佛即是心を參究し、即心佛 是を參究し、是佛心即を參究す。かくのごとくの參究、まさしく即心是佛、これ を擧して即心是佛に正傳するなり。 かくのごとく正傳して今口にいたれり。いは ゆる正傳しきたれる心といふは一心一切法、一切法一心なり

Then again, [the Buddhas and ancestors] exhaust their involvement with 'precisely mind is Buddha,' they exhaust their involvement with 'mind precisely Buddha is,' they exhaust their involvement with 'Buddha precisely-is mind,' they exhaust their involvement with 'precisely-mind Buddha is,' they exhaust their involvement with 'is Buddha mind precisely.' Having thus exhausted their involvement, [they realise that] the very mind is Buddha and raise as the correct transmission 'precisely mind 
is Buddha.' And this is how it has been handed down to us to this day. Thus the mind that we say has been handed down is that one mind is all dharmas, all dharmas are one mind. (Dōgen, 1972a, pp. 84-85)

Kim reads this passage as an example of random reshuffling of lexical components (1985, pp. 61-62). However, it is obvious that one certain combination has emerged from the clash as victorious. The text does not say that the other combinations of the four sinograms are senseless or incorrect, but that the particular one of 即心是佛 'precisely-mind is Buddha' (for the sake of consistency, I have translated 即 soku in all contexts as 'precisely') is the one to be handed down. We can hardly say that this is the most appropriate order of words-for the same semantic content, a sentence patterned on the Heart Sutra (心即是佛 'mind precisely-is Buddha') would clearly rather be the one expected, but it does not even appear among the permutationsthough we cannot also say that the order is random. In the present case there is also an organising principle explicitly present in the sentence in the guise of a lexical unit very close in its meaning to the total relation, namely the particle 即 soku (see Raud, 2003, for a discussion of the provenance and philosophical role of this particle). And quite clearly the concept has emerged not as a result of the displacement of some natural relation between sinograms, but out of a clash in which seemingly logical and illogical combinations of lexical units have had the same status, itself not being markedly a part of either group. Similar examples abound throughout Dōgen's text:

いはゆる如水中月の如如は水肘るべし c水如 月如、如中、中如なるべし 似を如と道取するにあらず、如は是なり。

The likeness of the 'like' in [the expression] 'like the moon in the water' is the water-moon [relation]. It is water-like, moon-like, like-in, in-like. We should not understand this 'like' as a relation of resemblance. 'Like' is 'it-is.' (Tsuki, (Dōgen, 1972a, p. 278)

Here he explicitly posits the two sinograms 水 and 月 next to each other in a markedly undefined (and therefore total) relation to each other as a clarification of what 如 'like' actually means-not an indication of similarity, of course, but of immediate identification. All these words, 即, 如 and 是 indicate a relationship between entities that dissolves their borders, merges their principles into a ground that is fundamentally same, but where all the possible relations between their surface manifestations are possible. Moreover, it becomes relatively unimportant what these entities are: the generative power of the total relation is absolute and it can perform the same operation on any lexical material—although, we may note, some of it yields philosophically much more interesting concepts such as 有時 uji 'existential moment,' while in some other case we may have to make do with 成荆棘 jokeikyoku 'becoming brambles' (Dōgen, 1972b, p. 126) or something similar, where it really does not matter very much what the words are in a particular case. In this way, we can say that Dōgen's concepts are all created by this same total relation between sinograms that, in its totality, is also empty. Thus we can also say that Dōgen's concepts are fundamentally engendered by emptiness as the constitutive principle of his language. 


\section{Conclusions}

I have proposed two ways to explain Dōgen's linguistic behaviour against the background of the shifts that took place especially in Japanese, but also in Chinese linguistic practice of his times, and also against a more general view of Chan/Zen language. According to the first narrative, Dōgen's aim was to liberate his means of expression, his parole, from a culturally and linguistically imposed logic that projected the most likely interpretation of a text unto reality and limited the freedom of both speakers and recipients to deviate from the mainstream, and he did this by deliberately displacing and ignoring the proper relations between sinograms in texts he relied upon. According to the second, however, he rejected not just the logic that related speech to reality, but the whole system of proper relations between lexical units, replacing them with a total relation that contained all others, an empty space between words that was nonetheless absolute in its generative power. Indeed these two explanations are mutually incompatible, because we either postulate a particular relation (displaced or otherwise) between two sinograms or we do not. However, this dichotomy can be overcome, if we bring back into play the two-tiered structure of langue and parole. The first narrative, in this case, describes the subversion that takes place on the level of parole, while the second deals with the reduction of the langue. In one case, we are left in command of the association mechanism, facing the isolated building blocks of the linguistic reality, in the other, we face the empty relation that is itself able to generate concepts out of lexical units that have been demoted to contingencies. The result, in both cases, is a proto-text thought-in-Chinese, which is then opened up to the Japanese necessity of spelling out how the expression proceeds. But this need, maybe even more than the things Dōgen talks about, is what reveals his thought to us: by taking us inside the concept, he shows how the generative power of the empty relation reconfigures our speech and the concepts it consists of.

\section{References}

Barthes, R. (1990). The fashion system. Berkeley: University of California Press.

Chen, P. (1999). Modern Chinese: History and sociolinguistics. Cambridge: Cambridge University Press.

Chomsky, N. (1965). Aspects of the theory of syntax. Cambridge, MA: MIT Press.

Deleuze, G., \& Guattari, F. (1994). What is philosophy? London: Verso Books.

Derrida, J. (2001). Writing and difference. London \& New York: Routledge.

Dōgen. (1972a). Vol.I. (T. Terada \& Y. Mizuno, Eds.) Nihon shisō taikei (Vol. 1). Tokyo: Iwanami. Dōgen. (1972b). Vol.II. (T. Terada \& Y. Mizuno, Eds.) Nihon shisō taikei (Vol. 2). Tokyo: Iwanami. Faure, B. (1991). The rhetoric of immediacy: A cultural critique of Chan/Zen Buddhism. Princeton: Princeton University Press.

Harbsmeier, C. (1998). Language and logic. Science and civilisation in China (Vol. 7). Cambridge: Cambridge University Press.

Heine, S. (2004). Koans in the Dōgen tradition: How and why Dōgen does what he does with koans. Philosophy East \& West, 54(1), 1-19.

Husserl, E. (1900). Logical investigations, trans. D. Moran. London \& New York: Routledge. 
James, W. (1904). A world of pure experience. The Journal of Philosophy, Psychology and Scientific Methods, 1, 533-543.

Kasulis, T. P. (1989). Zen action, Zen person (3rd ed.). Honolulu: University Press of Hawaii.

Kim, H. (1985). "The reason of words and letters": Dōgen and Kōan language. In W. R. LaFleur

(Ed.), Doggen studies. Studies in East Asian Buddhism (pp. 54-82). Honolulu: University of Hawaii Press.

LaCapra, D. (1989). Soundings in critical theory. Ithaca: Cornell University Press.

Liu, J. J. Y. (1966). The art of Chinese poetry. Chicago: University of Chicago Press.

Nishida, K. (1911). An inquiry into the good. New Haven, CT: Yale University Press.

Nishimura, E. (Ed.). (1994). Mumonkan. Tokyo: Iwanami.

Pinker, S. (1995). The language instinct. Harmondsworth: Penguin Books.

Raud, R. (2003). The genesis of the logic of immediacy. Asian Philosophy, 13(2/3), 131-143.

Takakusu, J., \& Watanabe, K. (Eds.). (1961). Mahāparinirvāna sūtra. In Taisho Taizōkyō (Vol. 12). Tokyo: Taishō Shinshū Daizōkyō Kankōkai.

Wang, K. (1998). The classic of the dao: A new investigation. Beijing: Foreign Languages Press.

Wang, Y. (2000). The pragmatics of "Never tell too plainly": Indirect communication in Chan Buddhism. Asian Philosophy, 10(1), 7-31.

Watts, A. (1957). The way of Zen. Harmondsworth: Penguin Books.

Wright, D. S. (2000). Philosophical meditations on Zen Buddhism. Cambridge: Cambridge University Press. 